\title{
Entre a corte e a revolução: a atuação de um "negociante" na América sede do Império português*
}

Andréa Slemian ${ }^{* *}$

O artigo discute a trajetória de Manuel Luís da Veiga que, como comerciante em Portugal (seu território natal), investiu na instalação de uma fábrica em Pernambuco após a chegada da família real no Rio de Janeiro, tendo em vista as transformações que à época se processavam no Império português. $O$ foco da análise centra-se no campo das sociabilidades políticas, com destaque para a atuação de Veiga na corte carioca e sua produção literária sobre economia política, entendendo-as como duas dimensões indissociáveis de sua prática social. Defende-se aqui que sua trajetória ilumina um mundo em profunda mudança nos seus paradigmas, impossível de ser sintetizado pelo estabelecimento de um padrão preciso de distinção entre o que era antigo e o que era novidade no início dos oitocentos.

Palavras-chave: Sociabilidades - Corte Joanina - Manuel Luís da Veiga

* Artigo recebido em outubro de 2007 e aprovado para publicação em dezembro de 2007.

** Pesquisadora do Instituto de Estudos Brasileiros-USP, financiada pela Fapesp (pós-doutorado), integrada ao Projeto Temático "Formação do Estado e da nação no Brasil: c.1780-1850", alocado na mesma instituição”. E-mail: slemian@usp.br. 
Between the court and the revolution: the role of one "merchant" in America, capital of portuguese Empire

The article discusses the trajectory of Manuel Luis da Veiga which, as a merchant in Portugal (where he was born) invested to install a factory in Pernambuco after the arrival of Real Family in the Rio de Janeiro, considering the changes, in these days, in the Portuguese Empire. It focuses the political sociabilities, remarking the role of Veiga in the court and his writings on political economy, understanding both as two linked dimensions of his social practice. It points out that his trajectory shows a deeply changing world in terms of paradigms, impossible to be understood simply in patterns of what was old or new in the beginning of XIX century.

Keywords: Sociabilities - D. João's Court - Manuel Luís da Veiga

Entre la cour et la révolutión: le métier d'un «marchand» dans l'Amérique quand elle a été siège de l'Empire portugais

L'article présente la trajectoire de Manuel Luis da Veiga, marchand au Portugal, où il est né L'article présente, qui a investi dans l'édification d'un établissement industriel à Pernambuco après l'arrivée de la famille royale à Rio de Janeiro, dans le contexte des transformations subies à l'époque dans l'empire portugais. L'étude se détient en particulier sur les sociabilités politiques, en soulignant l'action de Veiga dans la Cour de Rio de Janeiro et sa production littéraire dans le domaine de l'économie politique, en concevant ces dimensions de sa pratique social comme indissociables. On soutient dans l'article le caractère emblématique de cette trajectoire dans la mesure où elle exprime un monde dont les paradigmes sont en train de changer en profondeur, sans que soit possible de préciser exactement les normes d’après lesquelles on pourrait distinguer entre ce qui était ancien et ce qui était nouveau aux débuts du XIXème siècle.

Mots-clés: Sociabilités - Cour Joanina - Manuel Luís da Veiga

Em maio de 1810, o conselheiro da Fazenda da corte joanina no Rio de Janeiro, José Egídio Álvares de Almeida, informava ao intendente geral da polícia, Paulo Fernandes Viana, uma suspeita singular. Afirmava que um sujeito chamado Manuel Luís da Veiga, antes de partir para Pernambuco, dissera a pessoa de sua amizade que ali "estava para haver um motim, que havia de principiar por gritaria de moleques, a que deviam seguir coisas muito grandes; que correriam rios de sangue". ${ }^{1}$ Teria dito também que estava muito contente

${ }^{1}$ Arquivo Nacional do Rio de Janeiro (ANRJ), Coleção Devassas, caixa 2754, 4. Classe, série A, fl.3. Esse documento foi transcrito na íntegra por Andréa Slemian, Vida política em tempo de crise: Rio de Janeiro (18081824), São Paulo, Hucitec, 2006, p. 219-283. A mesma devassa foi citada e analisada por Kirsten Schultz, Tropical Versailhes. Empire, monarchy, and the Portuguese Royal Court in Rio de Janeiro, 1808-1821, New York/Londres, Routledge, 2001, quando analisa os conflitos ocorridos na cidade em torno dos tratados de comércio de Portugal com a Inglaterra em 1810. 
com a notícia, da qual teve conhecimento num jantar em que dera juramento de manter segredo acerca da identidade das pessoas que lá compareceram.

Três dias depois de saber de tal fato, Viana mandou uma carta ao desembargador ouvidor da comarca de Pernambuco para que imediatamente procurasse o tal Veiga. A ordem era para interrogá-lo sobre todos os pormenores acerca do tal motim, pois já seria "culposo em o não ter denunciado" quando ainda estava na urbe carioca. ${ }^{2}$ Ao responder às primeiras perguntas que lhe foram feitas no Recife, Veiga tanto negou o "motim" como igualmente acusou um oficial graduado da Secretaria de Estado dos Negócios da Marinha e Domínios Ultramarinos, Francisco Xavier de Noronha Torrezão, de fazer críticas ao governo. Ao saber disso, o intendente mandou chamar ambos os citados, colocou-os na prisão e instituiu uma devassa. A mesma transcorreu entre os meses de junho e novembro de 1810 e, sem conseguir chegar a um consenso acerca da culpa dos envolvidos, foi encerrada após verdadeiro impasse.

À semelhança de uma "comédia de erros", o processo poderia ser classificado sem maiores significados políticos se não fossem duas articuladas razões: o clima de controle de qualquer tipo de prática considerada desviante por parte do governo joanino; e a trajetória de Manuel Luís da Veiga que, nesse momento, pôde ser considerado suspeito. Quanto à primeira, é sabido que a monarquia portuguesa conseguira, ao menos momentaneamente, manter sua legitimidade cruzando os mares em 1807 em direção ao Brasil, ao contrário de sua vizinha espanhola, cujo rei foi mantido em cativeiro pelas tropas napoleônicas. ${ }^{3} \mathrm{O}$ clima no mundo atlântico, desde a eclosão das revoluções liberais em finais dos setecentos e a implantação de um novo paradigma de governabilidade, era francamente hostil às antigas estruturas monárquicas que passariam a ser acusadas de "absolutistas". No mesmo sentido, o surgimento dos primeiros focos de conflitos na América espanhola, que viriam a fornecer materialidade para os posteriores movimentos de Independência, agravava a situação de alerta das autoridades na corte no Rio de Janeiro contra qualquer comportamento tido como não desejável ao regime. ${ }^{4}$

\footnotetext{
${ }^{2}$ ANRJ, Devassa de 1810, fl. 32.

${ }^{3}$ István Jancsó, "A construção dos Estados nacionais na América Latina - apontamentos para o estudo do Império como projeto". Tamás Szmrecsányi e José Roberto do Amaral Lapa (orgs.), História econômica da independência e do Império, São Paulo, Hucitec/Fapesp, 1996, p. 3-26.

${ }^{4}$ A própria criação da Intendência Geral de Polícia, em 1808, no Rio de Janeiro, era uma prova dessa tentativa de controle político e social; sobre isso ver Maria Beatriz Nizza da Silva, "A Intendência Geral da Polícia: 1808-1821", Acervo. Revista do Arquivo Nacional, Rio de Janeiro, v. 1, n. 2, jul-dez./1986, p.137-251, e Andréa Slemian, op. cit. (cap. 2 e 3). João Paulo G. Pimenta, O Brasil e a América espanhola (1808-1822), São Paulo, FFLCH-USP, Tese de Doutorado, 2003, insere a questão no contexto revolucionário hispano-americano, evidenciando como a ação da corte joanina esteve permanentemente informada pelos acontecimentos políticos nos seus vizinhos.
} 
Manuel Luís da Veiga entra nessa história à medida que articulamos personagem e contexto. O "negociante", como ele próprio se intitulava, fora ao Rio de Janeiro com o intuito de conseguir uma provisão da Junta de Comércio para estabelecimento de uma fábrica em Olinda. Natural de Braga (Portugal), fixara residência nessa cidade após ter morado na Inglaterra. Era homem de instrução invulgar, autor de livros e folhetos sobre economia, nos quais se relevara um crítico mordaz às idéias defendidas por José da Silva Lisboa, o futuro Visconde de Cairu, acerca da liberdade de comércio. Por essa razão, seu pensamento é comumente classificado como "mercantilista" pelos poucos que se detiveram na análise de sua obra. ${ }^{5}$ A partir daí, seria cômodo supor que a principal explicação para as acusações da devassa teria relação com descontentamentos vinculados à política joanina de abertura dos portos em 1808, e que Veiga representaria os interesses da camada de comerciantes portugueses prejudicados com a medida e seus desdobramentos. E o fato de ele reivindicar privilégios junto à corte, para o funcionamento do seu novo negócio, reforçaria sua distância em relação aos preceitos e medidas liberais então em voga.

No entanto, sabemos que o mesmo Veiga, tendo voltado para Pernambuco após o encerramento do caso e colocado sua fábrica para funcionar, esteve envolvido, sete anos depois, no episódio da Revolução de 1817, quando foi caracterizado pelas autoridades como participante "entusiasmado". ${ }^{6} \mathrm{Seu}$ nome consta de uma lista dos que foram presos e posteriormente postos em liberdade com a condição de responderem, se necessário, pela sua conduta. ${ }^{7}$ Há indícios de que fazia parte de jantares maçons, cujos convidados "se gabavam de tratarem ali da rebelião", ${ }^{8}$ e de que teria se correspondido com os principais chefes do movimento. ${ }^{9}$ Levando em conta a profunda ruptura

\footnotetext{
${ }^{5}$ José Luís Cardoso (org.), Dicionário histórico de economistas portugueses, Lisboa, Cisep, 2001, p. 349-351.

6 “Revolução de 1817”, Documentos históricos, Rio de Janeiro, Biblioteca Nacional, 1954, v. 104 , p. 159.

${ }^{7}$ Idem, v. 102, p. 142.

${ }^{8}$ Idem, v. 104, p. 168.

${ }^{9}$ Segundo Joaquim Dias Martins (Os mártires pernambucanos victimas da liberdade nas duas revoluções ensaiadas em 1710 e 1817, Pernambuco, Typ. de F. G. de Lemos e Silva, 1853), Veiga tivera uma "pefeita união e corespondência (...) com todos os principais chefes da revolução", além de "juramento, que prestou à nova ordem de coisas; os oferecimentos da vida e fazenda, que fez para mantê-la [a revolução]; e os elogios que publicamente lhe dava" (p. 588).
} 
proposta pelos pernambucanos, ${ }^{10}$ antenada com os novos princípios políticos e constitucionais que rapidamente se difundiam pelo universo ocidental desde finais dos setecentos, ${ }^{11}$ é evidente a dificuldade em se enquadrar nosso protagonista em uma classificação que o identificasse estritamente num padrão de tipo Antigo Regime.

Reabrir o caso de 1810 tendo em vista a trajetória individual e as elaborações discursivas de Veiga nos permite lançar significativos problemas para compreensão tanto dos impasses vividos pelos coevos, como das formas de sociabilidades políticas então vigentes. Isso porque sua atuação é paradigmática de um mundo em transformação que, como veremos, era impossível de ser sintetizado pelo estabelecimento de um padrão preciso de distinção entre o que era antigo e o que era novidade no início dos oitocentos. ${ }^{12}$

Quando chegou ao Rio de Janeiro, Manuel Luís da Veiga tinha 37 anos e dizia já comerciar há 14 . De sua vida em Portugal quase nada se sabe, apenas que não estava matriculado na Junta de Comércio de Lisboa, ${ }^{13}$ talvez porque fizera parte de sua carreira no Brasil. Depois de morar na Inglaterra, aportou em Pernambuco em 1809, fixando residência em Olinda, onde instalou uma

${ }^{10}$ Sobre o caráter do movimento pernambucano, ver as análises de Carlos Guilherme Mota, Nordeste 1817: estruturas e argumentos, São Paulo, Perspectiva, 1972; e Evaldo Cabral de Mello, A outra independência. O federalismo pernambucano de 1817 a 1824, São Paulo, Editora 34, 2004.

${ }^{11}$ Reinhart Koselleck (Crítica e crise. Uma contribuição à patogênese do mundo burguês, Rio de Janeiro, Eduerj/Contraponto, 1999) analisa o longo e profundo processo do que tradicionalmente se convencionou chamar de crise do Antigo Regime na Europa por meio da transformação das concepções e sociabilidades políticas; ver também, do mesmo autor, Futuro passado. Para uma semántica de los tiempos históricos, Barcelona, Paidós, 1993 (em especial o capítulo "Modernidad"). Sobre o efeito devastador que os novos valores políticos tiveram na América portuguesa, ver István Jancsó, "A sedução da liberdade”, Laura de Mello e Souza (org.), História da vida privada no Brasil: cotidiano e vida privada na América Portuguesa, São Paulo, Companhia das Letras, 1997, v. 1, p. 387-437.

12 Nesse sentido, polemizamos com uma das proposições de François Xavier-Guerra e Annick Lempérière (que serve de base aos artigos à obra, por eles organizada, Los espacios públicos en Iberoamerica: ambiguidades e problemas. Siglos XVIII-XIX. México, Fondo de Cultura Económica, 1998), segundo a qual se poderia falar em concomitância de dois universos sociais e políticos bem distintos no período: um "moderno", vinculado aos novos valores, primeiramente tidos como ilustrados e posteriormente liberais, e outro "tradicional", ligado às monarquias de tipo Antigo Regime que, embora convivessem lado a lado, teriam sempre espaços circunscritos. Nesses termos, o sentido de ruptura trazido pelos "novos tempos" teria um permanente caráter de ambigüidade expresso por meio das continuidades da antiga ordem, tanto na Europa como na América.

${ }^{13}$ José Luís Cardoso (org.), op. cit., p. 349. 
fábrica de cordas. ${ }^{14}$ Tem-se notícia de que promoveu grandes benfeitorias nas terras do Araxá, as quais adquiriu em 1811 para construção do estabelecimento que tinha o título honorífico de Real Fábrica de Cordoaria de Pernambuco, em virtude de concessão conferida pelo governo. ${ }^{15}$

Versado em direito mercantil e em teorias comerciais e econômicas, Veiga estreou como autor de livros e impressos no ano de 1803, quando publicou três de suas obras. A primeira delas, um manual de contabilidade que ensinava a escrituração comercial pelo método conhecido por partidas dobradas. ${ }^{16}$ A segunda, um grosso volume intitulado Escola mercantil sobre o comércio antigo como moderno em que, após fazer um panorama da história do comércio e discorrer sobre as formas de produção dos bens (agricultura e artes), entra propriamente nos domínios mais práticos do funcionamento mercantil, além de analisar a situação de Portugal nesse ramo. ${ }^{17} \mathrm{~A}$ justificativa para sua apresentação ao público está marcada por um ideal racionalizante e utilitário da Ilustração setecentista, explicitado pela "necessidade que em Portugal havia das suas matérias mercantis para os negociantes do Reino, e suas colônias" no intuito de "facilitar as operações do seu comércio". No mesmo sentido, afirma não "omitir" nada que "pod[er]ia ser útil e de proveito para instrução" dos mesmos negociantes. ${ }^{18}$

Não há dúvida de que a ênfase da Escola Mercantil está em mostrar "o bem que resulta do Comércio em benefício dos Estados, e dos Povos", ${ }^{19}$ e no cuidado que demonstra em apontar medidas para torná-lo mais lucrativo.

${ }^{14}$ Inocêncio Francisco da Silva, Diccionario bibliographico portuguez, Lisboa, Imprensa Nacional; e Sacramento Blake, Dicionário bibliográfico brasileiro, Rio de Janeiro, Imprensa Nacional, 1900, vol. 6.

${ }^{15}$ F. A. Pereira da Costa, Anais Pernambucanos (1635-1665), Recife, Arquivo Público Estadual, 1952 , v. III, p. 512-516, afirma que no ano de 1813 a cordoaria era um estabelecimento regularmente montado que empregava matéria-prima local e produzia ampla qualidade de cabos de cairo (filamentos da casca do coco). Era dirigida por hábeis profissionais que vieram de Lisboa e tinha, na época, um efetivo de 60 escravos. Segundo ele, a fábrica foi fechada em 1829, quando já reduzira drasticamente o número de oficiais e escravos empregados no negócio devido à crise econômica então vivida. Veiga teria falecido logo após o fechamento do negócio, tendo deixado aos seus descendentes considerável fortuna. Na época, a denominação da Travessa do Veiga, em Olinda, foi dada para o local onde ficavam os edifícios da cordoaria.

${ }^{16}$ Novo método das partidas dobradas, para aqueles que não tiverem freqüentado a aula de Comércio, Lisboa, Oficina de António Rodrigues Galhardo, 1803.

${ }^{17}$ Escola mercantil sobre o comércio antigo como moderno entre as nações comerciantes dos velhos continentes, Lisboa, Oficina de António Rodrigues Galhardo, 1803. Segundo José Luís Cardoso, Dicionário histórico..., a obra servia bem à instrução dos negociantes da época pelo exame que fazia do funcionamento do comércio e das atividades econômicas portuguesas.

${ }^{18}$ Escola mercantil sobre o comércio antigo..., p. VII.

${ }^{19}$ Idem, p. VIII. 
Veiga constrói seu raciocínio sobre a centralidade do equilíbrio da balança de comércio como base para independência dos Estados e, com isso, estabelece que abandonar os negócios da Ásia e enfraquecer a importação de fazendas da Inglaterra seria muito favorável à situação de Portugal. ${ }^{20}$ Para ele, a solução seria incentivar o consumo dos lanifícios nacionais - e, nesse sentido, se permite fazer uma crítica ao "luxo" daqueles que compravam panos importados de melhor qualidade -, já que os "produtos da Natureza", produzidos sobretudo nos domínios, faziam a atividade comercial portuguesa florescer. ${ }^{21} \mathrm{O}$ livro conheceria ampla divulgação e seria reeditado em 1817 pela Impressão Régia de Lisboa sem conhecimento prévio de seu autor - conforme deixa claro um texto de "advertência do editor" ao informar ter-se custeado a nova edição em função da "grande falta" que se experimentava do livro "há mais de dez anos" e, sem "intenção de usurpar a este bom Cidadão uma propriedade tão importante", se lhe daria contas assim que ele se manifestasse.

A terceira obra de Veiga que saiu no mesmo ano de 1803 foi uma análise dos Princípios de direito mercantil, de José da Silva Lisboa ${ }^{22}$ que, pelo teor das críticas, teria causado alvoroço entre seus compatriotas portugueses. Desde o "Prólogo", Veiga faz críticas contundentes ao futuro Visconde, apontando para "contradições e incoerências" que o livro teria. Além de recriminar seu autor por ter copiado páginas inteiras da Ordenação francesa sobre seguros, ele faz a defesa das costumeiras práticas de comércio contra as novas medidas propostas por Silva Lisboa. É clara sua tentativa de resguardar o espaço de segurança dos comerciantes, como no ataque à medida que não estabelecia os seguradores como responsáveis pela vida dos escravos, pois que muitos deles se suicidavam no meio da travessia da África ao Brasil para grande prejuízo do traficante. ${ }^{23}$

Nesses textos, é evidente como Veiga mostrava-se temeroso em relação às vantagens que o ideal de livre-mercado, tão em voga desde o século anterior, poderia trazer para o comércio em Portugal, visto que defendia a proteção da produção nacional, bem como a manutenção de práticas já costumeiras nesse campo. Cinco anos depois, em 1808, encontramos o negociante na Inglaterra, onde publicaria dois panfletos unidos que, sem alterar significativamente

\footnotetext{
${ }^{20}$ Idem, p. 288.

${ }^{21}$ Idem, p. 300.

${ }^{22}$ Reflexões críticas sobre a obra de José da Silva Lisboa 'Princípios de Direito Mercantil' feitas por um homem da mesma profissão, Lisboa, Oficina de António Rodrigues Galhardo, 1803.

${ }^{23}$ Idem, p. 6.
} 
o conteúdo de seu pensamento econômico, apontavam para novos problemas. ${ }^{24}$ O primeiro texto propunha-se a informar aos seus "compatriotas" as péssimas condições que seus negócios encontravam em terras inglesas, onde o tratamento recebido por eles estaria muito longe do que seria esperado de "nações amigas e aliadas". ${ }^{25}$ Das várias irregularidades cometidas, centra-se na denúncia da ação de uma comissão organizada por "respeitáveis comerciantes" portugueses para defender os interesses de todos, cujos membros não cumpririam com seus deveres por agirem de maneira "despótica" e colocarem em risco os bens dos proprietários. Acusando os britânicos de se valerem de "tramas sofisticas do Comércio" para angariarem maiores lucros, ${ }^{26}$ dá a entender que o governo de Portugal deveria fornecer maior atenção aos interesses de seus negociantes no sentido de evitar as injustiças de que estariam sendo vítimas nas operações internacionais. A justificativa é que os "homens úteis à Nação", que faziam a riqueza do Império, deveriam receber semelhante contrapartida.

Até aí não havia grande novidade no seu discurso, cuja lógica estava centrada na proteção que o Estado deveria estender ao comércio nacional. No entanto, o momento era outro. Com a vinda da corte para o Rio de Janeiro, a abertura dos portos a todas as "nações aliadas", como é sabido, foi sua conseqüência lógica e imediata. Nesse sentido, Veiga enuncia uma nova preocupação, a qual está esmiuçada no texto que se segue na mesma edição, e que trata das conseqüências da entrada dos ingleses no Brasil. Partindo do pressuposto de que, em 1808, os negociantes portugueses não teriam como concorrer com os ingleses (pelo fato de não possuírem seus créditos estabelecidos na Ilha britânica), defende que o governo deveria restringir a liberdade que estes últimos tinham no estabelecimento de seus agentes na América. ${ }^{27}$ Ia, portanto, claramente contra as medidas, informadas pelo ideal de livre-comércio, colocadas em prática pela corte joanina logo que aportara no Novo Continente. ${ }^{28}$

\footnotetext{
${ }^{24}$ Trata-se da Analyse dos factos praticados em Inglaterra, relativamente às propriedades portuguesas de Negociantes rezidentes em Portugal, e no Brasil e das Reflexões políticas, sobre o estabelecimento dos Negociantes ingleses no Brasil, Londres, W. Glendinning, 1808.

${ }_{25}^{25}$ Analyse dos factos praticados em Inglaterra..., p. 1.

${ }^{26}$ Em suas palavras: "Se Argus tivesse Contas com os Negociantes Ingleses ainda não seriam bastantes os seus cem olhos para examinar como elas o devem ser" (p. 22).

${ }^{27}$ Reflexões sobre o estabelecimento dos Negociantes..., p. 32-33.

${ }^{28}$ Sobre a ascensão das idéias de livre-comércio e da economia política no período, preconizadas por José da Silva Lisboa, ver Antonio Penalves Rocha, A economia política na sociedade escravista (um estudo dos textos econômicos de Cairu), São Paulo, Hucitec/Depto. de Históra-USP, 1996; e também "Economia política e política no período joanino", Tamás Szmrecsányi e José Roberto do Amaral Lapa (orgs.), op. cit., p. 27-43.
} 
Mas a lógica central de sua argumentação tinha um elemento de fundo distinto daquele de anos antes. Veiga é enfático ao afirmar que o Brasil, "visto não ter fábricas próprias", seria agora totalmente dependente dos produtos manufaturados da Inglaterra, já que esta, de seus produtos primários, só importava o algodão. Além do transtorno que isso geraria do ponto de vista de seu saldo comercial, a admissão de liberdade para os ingleses tanto inibiria o aumento de manufaturas como desanimaria os "lavrados", com a "sepultura" do numerário do país. O problema seria propiciar aos produtos nacionais um preço "cômodo, ou ao menos igual" àqueles vendidos pelos ingleses, com os quais a concorrência era então impossível. ${ }^{29}$

Portanto, se a América portuguesa anteriormente aparecia com a função de celeiro para a metrópole (como era o caso na Economia mercantil...), agora ela assumia uma importância inédita para o comerciante, ao deixar de ser vista como "domínio" em função de um programa de desenvolvimento manufatureiro interno. Diz ele serem esses os "interesses da Nação Brasileira e de seu Comércio em geral" e que, por isso, "os estímulos de um patriotismo natural" o incitaram a escrever "estas Reflexões há tempo de se poderem remediar os danos futuros da nossa Pátria (deixem-me chamar-lhe assim)". ${ }^{30}$ Assim, como "bom Patriota", acreditava ter cumprido com seus deveres não com Portugal, mas com o Brasil.

Outra novidade, de não pequena monta, é possível de ser marcada nesses últimos escritos. Sob a defesa do mesmo "interesse da Nação", o comerciante se justificava pelo fato de prescindir de falar "em nome" de Domingos de Souza Coutinho - ministro na corte de Londres desde 1802 -, a quem devia "atenção e submisso respeito". Isso porque acreditava que todas as arbitrariedades que iria relatar, apesar de estarem sendo cometidas sob sua administração, não deveriam ser tomadas como uma ofensa pessoal, mas por poder "falar abertamente em um País onde se respeitam os direitos do Homem; onde todos são sujeitos à análise de seus fatos, e crítica dos seus costumes", ${ }^{31}$ qual seja, a Inglaterra. A despeito de o mesmo hábito ser incipiente entre os portugueses, os ventos das revoluções já haviam colocado em risco a base de legitimação das antigas monarquias, em especial a capacidade de seu controle por meio de censura e repressão às práticas e escritos considerados desviantes. O posicionamento de Veiga era a prova mais evidente dessa

\footnotetext{
${ }^{29}$ Reflexões políticas, sobre o estabelecimento dos Negociantes..., p. 35-36.

${ }^{30}$ Idem, p. 38.

${ }^{31}$ Analyse dos factos praticados em Inglaterra..., p. ii.
} 
transformação em curso. Ao evocar o "Tribunal da Censura pública" como único capaz de julgar as opiniões, ele operava na lógica dos novos tempos em que os indivíduos deveriam se posicionar publicamente sobre os negócios de Estado, anteriormente circunscritos apenas à esfera da corte.

O Rio de Janeiro joanino viveria especial tensão no entroncamento da pressão pelo nascimento de uma crítica aberta ao governo com a tentativa de preservação da legitimidade dinástica, tão cara aos Bragança nesse momento. Era exatamente para lá que o comerciante se encaminharia após ter publicado os panfletos de $1808^{32}$ e decidido fixar definitiva residência em Pernambuco, levando na bagagem tanto teorias afeitas às tradicionais práticas comerciais como de defesa da criação de um espaço de opinião pública moderno.

O fato de Manuel Luís da Veiga ter escolhido o Brasil como "pátria" e chamá-lo, em 1808, de "Nação" convergia com o projeto de um Império luso-brasileiro que, com a valorização política da colônia, vinha sendo uma alternativa cara à alta cúpula joanina do século XVIII. ${ }^{33} \mathrm{~A}$ instalação da família real no Rio de Janeiro coroaria tal empreendimento à medida que a alteração da sede do poder imperial se traduziria numa série de medidas que buscavam fortalecer tanto econômica como estrategicamente o novo continente. ${ }^{34} \mathrm{Um}$ dos seus desdobramentos seria a elevação do Brasil à condição de Reino em 1815 diante do fato de D. João mostrar-se resoluto a ainda permanecer na América, mesmo com a derrota napoleônica na Europa. Era afinado com esse projeto que Hipólito José da Costa, já no primeiro número do pioneiro Correio

\footnotetext{
${ }^{32}$ Sabe-se que Veiga teria escrito mais dois livros: um Sistema de educação, e um outro de poesia intitulado Retrato de formosura, dos quais não temos muitas notícias.

${ }^{33}$ Maria de Lourdes Vianna Lyra (A utopia do poderoso império. Portugale Brasil: bastidores da política 1798-1822, Rio de Janeiro, Sette Letras, 1994) defende uma evidente continuidade desse projeto na gestação do Império do Brasil, cuja gênese estaria no universo ideológico da ilustração portuguesa; Fernando A. Novais (Portugal e Brasil na crise do Antigo Sistema Colonial (1777-1808), 4. ed., São Paulo, Hucitec, 1986), analisa a valorização dada à colônia na política colocada em prática pelos ilustrados portugueses desde meados dos setecentos, e de como a alternativa da vinda da corte ao Brasil foi seu ponto culminante com a extinção da relação colonial.

${ }^{34}$ Segundo Valentim Alexandre (Os sentidos do Império - questão nacional e questão colonial na crise do Antigo Regime Português, Porto, Afrontamento, 1993), houve uma ênfase na "política americana" nos anos da corte joanina no Rio de Janeiro, a qual gerou grandes descontentamentos em Portugal e contribuiu para a eclosão da Revolução do Porto de 1820. Sobre o crescimento dos investimentos na América, em especial no Centro-Sul, ver Maria Odila da Silva Dias, "A interiorização da metrópole" (1972), A interiorização da metrópole e outros estudos, São Paulo, Alameda, 2005, p. 7-37.
} 
Braziliense, falava em "Império do Brasil", passando a publicar sistematicamente matérias que dissessem respeito a melhorias na vida e administração do seu imenso território. ${ }^{35}$

A viagem empreendida pelo negociante em 1809 ao Rio de Janeiro para regularizar e pedir privilégios à sua fábrica em Olinda - onde possuía sociedade com um inglês chamado João Guilherme Purcell - atesta o papel central que a nova corte adquirira em detrimento de Lisboa. Afinal, a lógica de ascensão político-social era diretamente pautada na justificativa de se fazer servir ao rei e daí ser conveniente dirigir-se, de preferência pessoalmente, à sede imperial. Nesse sentido, foram dois os requerimentos que na época Veiga encaminhou ao príncipe regente: o primeiro pedia a mercê de nomeá-lo "Inspetor da Agricultura" em Pernambuco, "pois muito observou que pod[er]ia melhorar" ${ }^{36}$ a situação dessa atividade. Para tanto, enviou em anexo um plano de agricultura para a capitania, no qual dizia que cuidaria de aumentar e diversificar as plantações, dar informações aos lavradores, além de melhorar as estradas.

O segundo requeria para sua fábrica em Pernambuco "a Graça de lhe conceder as mesmas Graças, Isenções, e Privilégios que V.A.R. foi servido conceder, como Protetor da Indústria Nacional". ${ }^{37}$ A base para tal pedido era a recente aprovação de um alvará no mesmo ano de $1809^{38}$ que, entre outros, isentava de "pagar direitos" a todas as matérias-primas que servissem de base a qualquer manufatura, além de determinar "privilégio exclusivo" aos inventores e introdutores de alguma "nova máquina e invenção nas artes". A justificativa era que sua cordoaria, já em funcionamento, fazia uso do cairo - material retirado da casca do coco e fartamente encontrado nas terras do Norte - para confecção de cabos e amarras por meio de técnica desconhecida nos domínios portugueses, embora já praticada na Índia inglesa. Alegava que

${ }^{35}$ A citação é do Correio Braziliense ou Armázem Literário, junho de 1808, v. 1, n. 1, p. 57. István Jancsó e Andréa Slemian, "Um caso de patriotismo imperial", Hipólito da Costa e o Correio Braziliense, São Paulo/Brasília, Imprensa Oficial do Estado/Correio Braziliense, 2002 (v.XXX, Estudos), analisam como Hipólito foi um dos que, na época, defenderam a centralidade do Brasil como base para um projeto de urgente modernização do Império português.

${ }^{36}$ Biblioteca Nacional (BN), Seção de Manuscritos, localização: C-111-39, $1^{\circ}$. doc.

${ }^{37}$ Idem, $3^{\circ}$ doc.

${ }^{38}$ Colleção das leis do Brazil de 1809, Rio de Janeiro, Imprensa Nacional, p. 45-48, Alvará de 28/abril/1809 que "isenta de direitos às matérias-primas do uso das fábricas e concede outros favores aos fabricantes e da navegação Nacional". Antes desse, o príncipe regente aprovaria um outro, de $1^{\circ}$. de abril de 1808 , que revogava a anterior proibição de instalação de manufaturas no Brasil e nos demais domínios ultramarinos; ver José Luís Cardoso, O pensamento econômico em Portugal nos finais do século XVIII - 1780-1808, Lisboa, Estampa, 1989, p. 198. 
a empresa, "totalmente feita a sua própria custa", "com dinheiro do Suplicante" e de outros interessados, poderia resultar em "vantagens consideráveis ao Estado" pela possibilidade de se evitarem as importações de cordas para a navegação nacional.

Dessa forma, Veiga confirmava a crescente valorização que o Brasil adquirira no contexto político-econômico português, já que, além de fixar residência desse lado do Atlântico, apostava no desenvolvimento interno da porção americana do Império, iniciando uma nova atividade manufatureira. Talvez o fizesse também por não vislumbrar na livre concorrência com os ingleses vantagens imediatas para os comerciantes seus compatriotas, como já se referia anteriormente ao propor como solução exatamente a criação de formas de incentivo para produção e utilização das "artes" nacionais. Para tanto, e a despeito de qualquer pressão inglesa para abertura irrestrita dos mercados, citava casos de "indústrias nacionais" que haviam recebido privilégios especiais (como era o caso dos benefícios que cita da "fábrica de papel Guimarães", dados em 1805, e da "Companhia de Vinhos do Alto Douro"), sem cuja proteção não teriam como sobreviver dignamente.

O alvará de 1809 deixava claro que a necessidade de "promover a indústria de qualquer ramo nascente" esteve igualmente entre as preocupações da corte joanina. Nele ordenava-se a retirada de uma quantia anual da "loteria nacional" a favor das "manufaturas e artes que mais necessitarem desse socorro, particularmente das de lã, algodão, seda, fábricas de ferro e aço" (parágrafo V). Para os ditos "inventores e introdutores" seriam concedidos "privilégios exclusivos por quatorze anos" depois de reconhecidos pela Real Junta do Comércio, que deveria julgar a "verdade, e fundamento" dos pedidos apresentados (parágrafo VI). ${ }^{39} \mathrm{O}$ pedido de Veiga não destoava, portanto, dessa diretriz geral.

No entanto, não há notícia de sua nomeação para o cargo de "Inspetor da agricultura", e os "privilégios exclusivos" requeridos lhe foram negados pelo Tribunal da Junta de Comércio, conforme resolução para funcionamento de sua cordoaria, que estabelecia "somente as graças, isenções e privilégios que possuem todas as outras fábricas". ${ }^{40}$ Foi quando escreveu uma longa carta diretamente à "Vossa Alteza Real", reivindicando a "graça” do pedido negado pela primeira instância régia, e argumentando detidamente por que seu

\footnotetext{
${ }^{39}$ Idem.

${ }^{40} \mathrm{BN}$, Seção de Manuscritos, localização: C-111-39, 4. doc.
} 
negócio de cordas de cairo seria de grande valia para a "indústria nacional". ${ }^{41}$ Logo no início, Veiga afirma que é de seu interesse concorrer para o "aumento da felicidade pública" e "bem da Pátria", seguindo as "paternais intenções de V.A.R." de promover os principais ramos da atividade produtiva, "objetos estes que sempre mereceram a Real Proteção". ${ }^{42}$ Nesse sentido, coloca-se como merecedor não apenas da "benigna Proteção" mas até do "prêmio" indicado no alvará, segundo se praticaria na Inglaterra para aqueles que oferecessem serviços em nome da "utilidade da Nação" ${ }^{43}$

O negociante, que se tornara fabricante, enumera algumas razões que teriam sido motivos da negação de seu pedido, como o fato de ser sócio de ingleses (e não portugueses), ou de sua fábrica não parecer uma empresa vantajosa. Mas acredita que a principal causa era que possuía inimigos entre os deputados do Régio Tribunal, caso explícito de José da Silva Lisboa e também de Mariano da Fonseca, ambos defensores das idéias de livre-comércio. A partir daí, divide seu argumento em duas principais frentes: primeiro, em mostrar as vantagens de seu negócio; segundo, em atacar a idéia comum e perniciosa de "que os Privilégios exclusivos são prejudiciais ao Comércio, e contrários à boa política; [e] que a liberdade do Comércio é a mais conveniente ao Estado". ${ }^{4}$

Ao discorrer sobre a importância da introdução da cultura do cairo na fabricação de cordas no Brasil, principalmente na marinha, Veiga frisa a novidade do empreendimento. Como não constava "nem da História, nem da Tradição ter havido jamais outra alguma fábrica na Europa, nem América", 45 pouco importava o fato de não ser o descobridor da técnica desde que fosse iniciador de "alguma invenção útil nas Artes". Ironizava que nem "Colombo" nem "Vasco da Índia" poderiam então ser tratados como "descobridores da América" se considerassem que o continente já tinha sido noticiado por outros viajantes. Além disso, a empresa exigia grande cabedal, sendo que ninguém poderia "pôr em prática aquele comércio, e cultura do cairo sem que V.A.R. o proteja, favoreça, e premie com Privilégios; pois que para vencer poderosos obstáculos s[eriam] indispensáveis poderosos meios". ${ }^{46}$ Para que se tivesse a dimensão do negócio, escreve que um bom engenho de açúcar em operação

${ }^{41}$ Idem, $6^{\circ}$ doc.

${ }^{42}$ Idem, fl. 2.

${ }^{43}$ Idem, fl. 3.

${ }^{44}$ Idem.

${ }^{45}$ Idem, fl. 4.

${ }^{46}$ Idem, fl. 7. 
era então orçado em 80 contos de réis, enquanto sua companhia, formada por ele e seus sócios, reunia a considerável quantia de 120 contos de réis. Isso sem contar os 400 contos de réis que estimava para a matéria-prima a ser beneficiada, cujo total era um valor muito significativo à época.

Mas seu posicionamento mais enfático foi sobre a questão da proteção do Estado versus liberdade de comércio. Nesse sentido, inicia dizendo que, a princípio, nem todos os "privilégios exclusivos s[eriam] prejudiciais ao Comércio" como comumente propagandeavam seus críticos. No caso do cairo, em especial, afirmava que tanto ele seria "útil ao Estado" como não prejudicaria ninguém por "fornecer à Marinha Portuguesa todos os cabos e amarras precisos para sua navegação", sem necessidade de "comprar dos Russos aquele gênero de manufatura estrangeira que consome uma grande parte do numerário português". ${ }^{47}$ A base de seu raciocínio continuava informada pelo equilíbrio da balança comercial, em que classificava como "delírio" defender a "saída de dinheiro nacional" para outros reinos. ${ }^{48}$

No mesmo sentido, afirma que se a extinção da proteção fosse benigna ao Estado, "V.A.R. teria anulado já todos os Privilégios exclusivos do Reino (...) e se os conserva é por estar sabiamente persuadido que não são na realidade prejudiciais". ${ }^{49}$ Para provar a veracidade da afirmação, Veiga argumenta que os "privilégios exclusivos" são capazes de criar "vassalos poderosos", os quais, "nas circunstâncias da guerra, e em outras muitas ocasiões", enchiam "com seu dinheiro os [cofres] vazios do mesmo Estado". Este último, portanto, encontraria apoio permanente para sua prosperidade nos "ricos homens da Nação", para os quais as "companhias e os privilégios" eram formas de necessário enriquecimento. Afinal, pergunta, que "vantagens pode tirar um só Vassalo de per si, ou um débil corpo de companhia com pequenos fundos de capitais?". ${ }^{50}$ Conclui que o livre-comércio até poderia ser útil, mas não para essa classe privilegiada e mantenedora da economia nacional na qual se enquadrava para reivindicar sua "graça".

\footnotetext{
${ }^{47}$ Idem, fl. $5 \mathrm{v} .-6$.

${ }^{48}$ Para que se tenha idéia do debate existente sobre a questão das manufaturas no Brasil, vale dizer que José da Silva Lisboa defendia, na mesma época, ser demasiado "prematuro" seu desenvolvimento no Brasil. Para ele, a agricultura representaria a atividade mais importante para o "quadro econômico brasileiro", sendo as fábricas inadequadas a ele. Criticava os estímulos governamentais às atividades fabris como contrários às determinações do "sistema liberal". Antonio Penalves Rocha, "Economia política e política no período joanino”, p. 35-36.

${ }^{49} \mathrm{BN}$, Seção de Manuscritos, localização: C-111-39, $6^{\circ}$. doc., fl. 9.

${ }^{50}$ Idem, fl. 9v.
} 
Não há dúvida de que o tom de seus argumentos, os quais apontavam na direção de defender a doação de privilégios e de proteções como forma de reforçar os laços dos vassalos com o monarca, vinha bem a calhar num texto dirigido diretamente à "Vossa Alteza Real". No entanto, por mais que as tintas estivessem carregadas com vistas à aprovação do pedido, sua fala tocava no cerne da relação súdito-soberano desejada, em que o "espírito de patriotismo", tantas vezes mencionado por Veiga, passava diretamente não só pela defesa do Estado, mas também da monarquia. Por essa razão, seria arriscado supor que Veiga deliberadamente forjara palavras apenas para conseguir seu intento, já que ele próprio viria a participar de um atentado contra a instituição monárquica poucos anos depois, em apoio aos republicanos pernambucanos de 1817. Isso porque ambas as ações não se contradizem na trajetória de um personagem que viveu um momento em que os paradigmas políticos até então vigentes passavam por um momento de crise na base de sua legitimação, e que a ascensão de novas alternativas de regimes estava na agenda do mundo ocidental. O resultado foi que, nesse momento, a lógica tradicional de privilégios, em que ele claramente operava, produziu um efeito imprevisto nas redes de sociabilidade por ele tecidas na corte e acabariam levando-o a um impasse, conforme veremos a seguir.

* * *

Manuel Luís da Veiga foi obrigado a voltar ao Rio de Janeiro assim que foi localizado de volta a Pernambuco pelas autoridades locais em 1810, agora na condição de suspeito. Já nos primeiros interrogatórios a que foi submetido, contou uma outra versão do ocorrido nos encontros com Francisco Xavier de Noronha Torrezão na urbe carioca. Alegava que, tendo-o procurado "como pessoa de valimento na Corte a fim de o proteger" ${ }^{51}$ nos seus negócios, chegou a freqüentar sua casa, onde, cerca de 15 dias antes de sua partida, o mesmo lhe chamara a uma sala para se queixar de ser pouco atendido pelo governo; o que teria feito "depois de ter o cuidado de fechar as portas deixando só meia janela aberta". ${ }^{52}$ Logo em seguida, o teria questionado sobre a disposição do "Povo de Pernambuco" perante o Estado e sentenciado que "ainda o Brasil floresceria ficando livre do atual governo". ${ }^{53}$ Como dissera não concordar com

\footnotetext{
${ }^{51}$ ANRJ, Devassa de 1810, fl. 25.

${ }^{52}$ Idem, fls. $15 \mathrm{v}-16$.

${ }^{53}$ Idem, fl. 16.
} 
suas afirmações, Torrezão o teria ameaçado de morte caso revelasse o teor daquela conversa.

O mesmo Torrezão, quando efetivamente interrogado, confirmou as acusações já feitas contra Veiga - citadas no início do artigo -, fornecendo agora mais detalhes. Afirmou que ele falara, "coberto de alegria", sobre a possibilidade de uma "revolução" ou "motim" projetado por aproximadamente 40 negociantes, do qual soubera num jantar fora da cidade. Além disso, Veiga lhe teria confessado que "o Estado do Governo inspirava tão pouca confiança aos Negociantes do Rio de Janeiro que estes (...) o convidaram a uma assembléia". ${ }^{54}$

Ambos também se justificaram pelo fato de não terem contado a história às autoridades logo que a souberam, como seria do dever de um "bom vassalo". Torrezão, por ter dado "tão pouco peso a esta história", que lhe pareceu "tão pouco conseqüente" e "inventada [que] não se lembrou de a detalhar", ${ }^{55}$ sobretudo depois de passado o período que o fabricante estabelecera para a mesma acontecer. Veiga, "pelo risco de sua vida, pelo justo temor de o matarem". ${ }^{56}$ Assim, estava instaurada a devassa para cujo desenrolar e desfecho a trajetória de vida de cada um seria levada em conta. ${ }^{57}$

Se Veiga já era conhecido na corte pela sua atividade mercantil e escritos polêmicos, Torrezão o era por descender de família de "mui antiga Nobreza" 58 em Portugal e ocupar o cargo de oficial graduado da Secretaria da Marinha e Domínios Ultramarinos. Desempenhava tal função desde 1796, quando retornara ao Reino depois de residir oito anos na Corte de São Petersburgo como enviado português. Fora nessa condição que conseguira acompanhar, com sua esposa e nove filhos, a comitiva da família real na sua viagem ao Rio de Janeiro, a despeito de alguns contratempos políticos em que estivera envolvido anos antes: tratava-se de sua participação numa loja maçônica dirigida por Hipólito José da Costa em Lisboa, que, como atividade proibida pelo governo português, foi descoberta e fechada pelas autoridades em 1802, com

\footnotetext{
${ }^{54}$ Idem, fl. 39.

${ }_{55}^{55}$ ANRJ, Devassa de 1810, fl. 40.

${ }^{56}$ ANRJ, Devassa de 1810, fl. 18v.

${ }^{57}$ Vale dizer que a devassa se passou entre os meses de junho e novembro de 1810. Consta o documento de seis autos de perguntas a que foi submetido Veiga (dois em Pernambuco e os outros no Rio de Janeiro), quatro a que respondeu Torrezão, um auto de acareação, interrogatórios curtos de seis testemunhas, o parecer de Paulo Fernandes Viana, uma carta que Torrezão escreveu da prisão, ofícios trocados entre as autoridades do Rio de Janeiro e de Recife e um ofício do conde de Galveas mandando soltá-los.

${ }^{58}$ BN, Seção de Manuscritos, localização: C-190, 1.
} 
punição dos envolvidos.$^{59}$ Como é sabido, o mesmo Hipólito seria preso, tendo depois fugido para a Inglaterra. Torrezão, apesar de não ter sido condenado, foi repreendido por D. Rodrigo de Sousa Coutinho e pediu perdão pessoalmente a Sua Alteza Real, pelo que confessava ter sido "verdadeiramente culpado, mas não criminoso". ${ }^{00}$ Para tanto, valera-se da proteção do já citado José Egídio Álvares de Almeida e, desta forma, tanto permaneceu no cargo da Secretaria como embarcou na esquadra que veio para o Brasil em 1807.

Em 1810, o intendente Paulo Fernandes Viana sabia desses fatos, tendo declarado que "quem foi maçom [seria] capaz de tudo, por isso que quanto a mim nunca deixou [Torrezão] de o ser, e por este mesmo princípio o julgo capaz de conversa revolucionária". ${ }^{61}$ De outra parte, o fato de Veiga ter buscado no oficial proteção para seus negócios comprova que ele mantinha algum status de pessoa influente na corte. ${ }^{62}$

Verdadeiras ou não, as acusações recíprocas se assemelhavam muito em alguns pontos. Primeiramente, ambas referem-se a um desapreço pelo poder instituído e sugerem a possibilidade de movimentos sediciosos, seja pelo suposto motim projetado por negociantes, seja pela eminência de

${ }^{59} \mathrm{O}$ nome de Torrezão constava da lista daqueles que compunham a dita loja, chamada dos "Cavalheiros da Espada do Oriente", e uma das testemunhas afirmou que ele participava de "ajuntamentos de diversos sujeitos (...) os quais se fechavam todos na sala, não consentindo que ali entrasse pessoa alguma". Ver Instituto Histórico e Geográfico Brasileiro (IHGB), Documentos sobre a prisão de Hipólito José da Costa em Portugal, fls. 24-24v, e fl. 22. Alexandre Mansur Barata, Maçonaria, sociabilidade ilustrada छ̊ Independência do Brasil (1790-1822), Juiz de Fora/São Paulo, Ed. UFJF/Anna Blume/Fapesp, 2006, discute a relação entre maçonaria e sociabilidade política para o período, e cita a participação de Torrezão na instituição em Portugal (p. 101).

${ }^{60}$ ANRJ, Devassa de 1810, fl. 84v.

${ }^{61}$ Idem, fl. 6.

${ }^{62}$ Mesmo depois da repreensão recebida pelo caso de 1810, as coisas de Torrezão pareceriam seguir o mesmo fluxo, a despeito das dificuldades atestadas pelos fatos seguintes: em dezembro de 1813, ele requereu uma comenda da Ordem de Cristo por meio de uma carta, afirmando ser "o mais antigo de todos os Oficiais das Secretarias de Estado (...) [e que] vê Colegas seus muito mais modernos Comendadores e Conselheiros (...) que a Vossa Alteza mereceram seus bons serviços e merecimentos" (BN, Seção de Manuscritos, localização: C-190, 1). Essa petição parece não ter sido aceita, pois em 1815 Torrezão encaminhava outro requerimento em que pedia uma comenda da Ordem da Torre e Espada, submetendo-o ao arbítrio do Príncipe. Nessa segunda carta, além de reafirmar ser o oficial mais antigo das Secretarias, sugeria que "circunstâncias que a Vossa Real são conhecidas, tem privado o Suplicante, por desventura sua, de participar das Graças, feitas a alguns de seus Colegas, muito mais modernos”. Sem entrar em detalhes quanto a esse ponto, ele provavelmente se referia as suas desventuras políticas. Apesar de tudo, sabemos que conseguiu uma comenda por decreto de 15 de dezembro de 1815 e que um dos seus filhos, posteriormente, pediria solenemente o mesmo privilégio dado ao pai. Portanto, envolver-se com o que não devia pode lhe ter criado dificuldades, mas estava longe de lhe impedir a progressão política nos quadros dos funcionários da monarquia portuguesa. 
descontentamento do povo pernambucano, que poderia ser usado em alguma ação de tipo subversiva. Além disso, as duas reiteram que existiriam interesses diretamente atingidos pelas ações do governo, pois nem os negociantes nem Torrezão estariam satisfeitos e se mostrariam duvidosos quanto à política da corte. Se elas não indicavam alguma trama revolucionária verdadeiramente em curso, apontavam que a acusação poderia ser tomada, no mínimo, como verossímil.

Outra forte semelhança é que as acusações recíprocas giram em torno de situações que envolvem alguma forma de segredo. Em primeiro lugar, existia a suspeita de um jantar secreto, envolvendo 40 negociantes em uma casa de campo distante "quatro a seis léguas da cidade", e o juramento prestado pelo fabricante de não declarar os ditos negociantes. ${ }^{63} \mathrm{Ou}$ mesmo de que Torrezão teria levado Veiga para uma sala de sua casa e fechado as portas e janelas para manter uma conversa particular com ele. Completando o quadro, este último também acusava Torrezão de lhe haver proposto uma correspondência secreta, debaixo de um nome fictício do qual dizia não se lembrar. Ela seria escrita no branco do papel "com leite puro porque ele Torrezão (...) recebendo a carta deitar-lhe-ia por cima pó de carvão" para decifrar seu conteúdo. ${ }^{64}$

Tanto na concepção dos envolvidos quanto na das autoridades, fazer uso do segredo poderia encobrir a prática de alguma atividade atentatória ao regime. Assim, todas essas acusações têm por palco âmbitos privados de relações, enquanto os projetos estão centrados no espaço do público. ${ }^{65}$ Dessa forma, a possibilidade de realização de reunião, visando à trama sediciosa longe da cidade, ou mesmo de manutenção de correspondência secreta, norteou grande parte das perguntas feitas aos suspeitos, permanecendo sem respostas definitivas devido à ausência de provas conclusivas.

Por essas razões, a existência de relações ou momentos de intimidade entre os dois envolvidos também foi objeto perquirido pela polícia. Quanto a isso, tanto Veiga como Torrezão negaram com freqüência o estabelecimento de laços de amizade mais íntimos. Isso fica especificamente claro em três momentos: primeiro, quando perguntados sobre quem teria se oferecido para manter correspondência com o outro. Segundo Torrezão, ele negou a proposta

\footnotetext{
${ }^{63}$ ANRJ, Devassa de 1810, fl. 29.

${ }^{64}$ Idem, fl. 58v.

${ }^{65}$ Conforme discutido por Reinhart Koselleck, Crítica e crise..., para a Europa no processo de derrocada da monarquia absolutista desde o século XVIII. A cultura do segredo e sua especificidade na América portuguesa foi discutida por István Jancsó, “A sedução da liberdade”.
} 
de Veiga para se corresponderem depois de ter ouvido a tal história do motim; segundo o fabricante, o oficial teria lhe pedido para "informar da indisposição do Povo (...) e que o devia fazer em Carta remetida a ele Torrezão debaixo de um nome suposto". ${ }^{66}$

Num segundo momento, a intimidade é negada em um fato aparentemente sem conexão com o resto da devassa, e no qual Veiga acusou Torrezão de ter pego seu cavalo sem permissão. Como indicam as testemunhas, o episódio se passou no Natal de 1809, quando os dois estavam juntos em um sítio no Irajá, a algumas léguas da cidade. De acordo com um desses depoimentos, "o tal Homem [Veiga] gritara muito por lhe terem tirado o seu Cavalo [e] Torrezão sossegava o dito Homem dizendo-lhe que 'ali está o seu Cavalo". ${ }^{67}$ Daí, o fabricante incriminar Torrezão de haver tentado "ter mais intimidades" com ele e se defender ao afirmar que era contra os supostos planos de conspiração que o outro teria.

No mesmo sentido, a discussão sobre o passaporte para a volta de Veiga a Pernambuco também é significativa. Dissera este último que Torrezão, depois de lhe ter inquirido sobre o "descontentamento do Povo de Pernambuco", encontrara-o na rua e questionara-o sobre "que negócios tinha na Intendência Geral da Polícia, e respondendo [Veiga] que ia tirar o seu Passaporte, e que ia saber uma pessoa conhecida para o afiançar, ele [Torrezão] logo se ofereceu a tirar como tirou" ${ }^{68} \mathrm{O}$ oficial alegava, em contrapartida, que Veiga teria ido à sua casa dias depois de lhe contar do motim, e "com muito enfado lhe dissera tinham dificultado o seu Passaporte". ${ }^{69}$ Afirmava que apenas mandara um recado verbal para o porteiro da Intendência desembaraçar tal pedido, sem maiores demonstrações de envolvimento. Dessa forma, amizade, proximidade e intimidade poderiam significar, à época, o partilhamento das ações subversivas de que um acusava o outro.

No entanto, o que o mapeamento dos comportamentos dos envolvidos na devassa traz efetivamente à tona é o surgimento de formas de sociabilidade política, as quais marcaram fundo a trajetória, aparentemente desconexa, de nosso protagonista principal. Trata-se especificamente do engendramento de hábitos de discussão e crítica política ${ }^{70}$ que, como Veiga já denunciava estar na

\footnotetext{
${ }^{66}$ ANRJ, Devassa de 1810, fl. 58v.

${ }^{67}$ Idem, fl. 97.

${ }^{68}$ Idem, fl. 16.

${ }^{69}$ Idem, fl. 48.

${ }^{70} \mathrm{O}$ aparecimento de formas de sociabilidades semelhantes pode ser verificado nos casos dos ensaios de sedição ocorridos em fins do século XVIII na América portuguesa; István Jancsó, op. cit.
} 
pauta das transformações em seu panfleto escrito em Londres, surgiram em ambientes que se pretendiam, a princípio, de intimidade, ganhando inevitável publicidade pelo teor de suas polêmicas. Eram esses os tímidos germens de um processo de alargamento dos espaços da política e gestação, com todas as suas especificidades, de uma esfera pública moderna, em curso em todo o mundo ocidental. ${ }^{71}$

Indícios significativos dessa mudança no plano das sociabilidades estão presentes nas falas dos envolvidos na devassa. Era assim que Torrezão, ao tentar negar que tivesse dito a Veiga alguma coisa sobre a imposição dos tributos pela corte, afirmava ser bem possível que na sua presença ou "de outros sem nenhuma particularidade falasse de algum tributo imposto, ou [que] estivesse para se impor, ser menos, ou mais gravoso menos bem, ou mal pensado, como falam todos sem murmurar da sua imposição, nem do governo".72 Também o fabricante reconheceu ser comum acontecerem discussões na "estalagem da Inês", lugar em que se hospedava no Rio de Janeiro. Confessava que lá "ouvia falar em Novidades a respeito dos Franceses, sendo uns a favor destes, e outros contra". ${ }^{73}$ Para ambos, admitir que todos conversassem abertamente sobre questões políticas não parecia ser o problema.

No entanto, o que aparentemente poderia ser entendido como clareza de limites entre discutir política e conspirar contra o Estado revelava-se, na prática, de muito difícil definição aos olhos daqueles responsáveis pela repressão aos comportamentos desviantes. Num universo em que a crítica pública aos negócios do Império era repreendida, a delimitação entre falar e agir contra as ações do governo era tênue. Ainda mais num momento em que estava na pauta, em especial no Rio de Janeiro, a defesa e manutenção dos valores monárquicos frente à possibilidade de contaminação pela agenda revolucionária de fundo liberal. Assim, como distinguir precisamente entre quem falava da gravidade dos impostos e quem julgava sua imposição uma arbitrariedade? E mesmo o fato de discutir "novidades" em relação aos franceses estaria dissociado do posicionamento a favor ou contra os mesmos? Nestes termos, a indefinição entre o que era ou não perigoso aparecia como um reflexo tangível de uma crise de paradigmas que, além de tornar imprecisos os contornos do permitido, mostrava a impossibilidade de controle dos novos comportamen-

\footnotetext{
${ }^{71}$ Jürgen Habermas, Mudança estrutural da esfera pública, Rio de Janeiro, Tempo Brasileiro, 1984, passim.

${ }^{72}$ ANRJ, Devassa de 1810, fl. 43.

${ }^{73}$ Idem, fl. 15v.
} 
tos. Um exemplo igualmente paradoxal encontrava-se no Correio Braziliense que, como periódico proibido de circular em terras portuguesas (editado em Londres) ${ }^{74}$ era profusamente lido na América, inclusive entre os ministros da corte, devido à importância que adquirira enquanto formador de opinião nos círculos letrados. ${ }^{75}$

$\mathrm{Na}$ devassa, a implosão que as formas de sociabilidade moderna causavam na ordem social está também presente na perquirição das conversas que os dois envolvidos mantiveram sobre os tratados de comércio entre Portugal e Inglaterra. Como questão de interesse imediato para os negócios portugueses naquele momento, é evidente que eles trocaram juízos sobre o tema, para o qual, como sabemos, o fabricante tinha opinião consolidada. Segundo Veiga, Torrezão teria dito "que a condescendência do Brasil com a Inglaterra não [seria] boa", sendo rebatido pelo outro, para quem "o Brasil nas cirscunstâncias atuais precisa[ri]a da Inglaterra" ${ }^{76}$ Em outro momento, era Torrezão que incriminava Veiga de falar dos projetos dos tratados, "dizendo que estava escrevendo, ou que tinha escrito contra as doutrinas de José da Silva Lisboa". ${ }^{77}$

É fato que, desde a imposição do bloqueio continental por Napoleão Bonaparte à Europa, em 1806, a presença da Inglaterra nos negócios portugueses, que já era forte, aumentara significativamente. A abertura do comércio imperial com a chegada da família real no Rio de Janeiro favoreceu, como é sabido, os produtos e os interesses britânicos no novo continente, impondo uma reorganização das práticas comerciais mantidas pelos negociantes de ambos os hemisférios. Uma mostra do grau de tensão então desencadeado

${ }^{74}$ Uma prova de que o periódico, ainda que proibido, circulava está num anúncio do jornal a Idade d'Ouro no Brasil, editado na Bahia, de 1812, que noticiava a venda de exemplares do Correio Braziliense em sua loja (Maria Beatriz Nizza da Silva, A primeira gazeta da Bahia: Idade d'Ouro do Brasil, São Paulo, Cultrix/MEC, 1978, p. 129). O significativo número de leitores que possuía em território português está também comprovado na existência de um outro periódico intitulado Reflexões sobre o Correio Brasiliense - editado em Lisboa no ano de 1819 -, que tinha como objetivo uma polêmica com o citado jornal.

${ }^{75}$ Nesse sentido, não deixa de ser instigante o fato de o Correio Braziliense trazer à tona, em outubro de 1810, notícias sobre "certo sinal de descontentamento" de vassalos, quando "rumores públicos mencionam o fato de prisões, por crimes políticos, no Rio de Janeiro; e estes procedimentos, quando não são conduzidos com a maior prudência, em vez de acabar com o mal, ordinariamente o exacerbam. Quando existe em um povo certo sinal de descontentamento, o remédio não é seguramente reprimir, ou perseguir os primeiros descontentes de quem se lança mão (...) o remédio próprio é indagar a causa do descontentamento; permitir que os descontentes mesmo se expliquem; e remover a causa; porque naturalmente se remove o efeito".

${ }^{76}$ ANRJ, Devassa de 1810, fl. 58.

${ }^{77}$ Idem, fl. $52 \mathrm{v}$. 
estava na própria manifestação panfletária de Veiga no ano de 1808, quando as polêmicas acerca do futuro mercantil e manufatureiro do Brasil e de Portugal mantinham-se, mais do que nunca, na ordem do dia. ${ }^{78}$ No entanto, se anteriormente as idéias de economia política com base no livre-comércio encontravam uma barreira na defesa do exclusivo colonial, agora o que estava em questão era o debate entre a liberdade de comerciar e a manutenção dos privilégios por parte do Estado. Nesse sentido, a obra do fabricante era emblemática, bem como os conflitos ocorridos na recém-criada Junta de Comércio, Agricultura, Fábricas e Navegação no Rio de Janeiro, à semelhança de sua congênere lisboeta. ${ }^{79}$

De fato, poucos meses antes de se iniciar propriamente a devassa, um "Tratado de Amizade e Comércio" seria assinado com a Inglaterra, em fevereiro de 1810, com um nítido desequilíbrio de cláusulas e prerrogativas que asseguravam uma situação privilegiada para o lado inglês ${ }^{80}$ Sua aprovação geraria descontentamentos, sobretudo em Portugal, que à época já experimentava uma difícil situação político-econômica com a mudança da sede imperial. ${ }^{81}$ Obviamente a medida não seria bem vista por Manuel Luís da Veiga, que apontava os malefícios a serem trazidos pela livre-concorrência com a Inglaterra para o comércio e a produção manufatureira nacional, mesmo antes da assinatura do tratado.

Para Veiga, como interessado diretamente no assunto - em especial depois de fixar residência no Brasil, onde vislumbrou um futuro mais propício à sua atividade profissional em detrimento de Portugal -, a saída para o crescimento e a prosperidade do Império estaria na ação do Estado, por meio da garantia de melhores condições para os "indivíduos úteis à Nação". O que se traduziria na doação e obtenção de condições especiais ou privilégios aos

\footnotetext{
${ }^{78} \mathrm{O}$ já citado Hipólito José da Costa pedia aos comerciantes portugueses que, em 1809, lhe enviassem sugestões e exigências sobre os tais acordos em andamento, as quais serviriam de "armas" para refutar as "imposições inglesas expressas pelo negociador Strangford". Correio Braziliense, vol. III, p. 526-527. Kirsten Schultz, op. cit., também analisa o debate em torno da questão na corte.

${ }^{79}$ Cláudia Maria das Graças Chaves ("O outro lado do Império: as disputas mercantis e os conflitos de jurisdição no Império Luso-brasileiro”, Topoi. Revista de História, Rio de Janeiro, Programa de Pós-graduação em História Social da UFRJ/7 Letras, v. 6, n. 12, jan-jun. 2006, p. 147-177), analisa o conflito de interesses entre mercadores portugueses com a criação da Junta de Comércio no Rio de Janeiro, em que a questão dos privilégios para exercício de algumas funções era um dos pontos centrais de atrito.

${ }^{80}$ José Luís Cardoso, O pensamento econômico em Portugal, cap. VII; e Alan Manchester, Preeminência inglesa no Brasil, São Paulo, Brasiliense, 1973.

${ }^{81}$ Valentim Alexandre, op. cit, parte III, caps. 2 e 3.
} 
portugueses. Nesse sentido, também a Francisco Xavier de Noronha Torrezão interessava estar antenado com a questão, já que a manutenção de seu status pessoal na corte dependia de continuar sendo pessoa de "valimento" numa ampla rede de sociabilidade política que poderia incluir, inclusive, os círculos maçônicos. Assim, apesar de ser impossível decodificar, por meio da devassa, o que de verdadeiro haveria das discussões sobre os tratados travadas pelos protagonistas, é indiscutível que, naquele momento, o tema tocava diretamente em interesses particulares de ambos.

Portanto, as acusações trocadas no desenrolar do processo estavam longe de ser partes desconexas e vazias de significado, e iluminam a atuação política de nosso "negociante" na corte. A articulação entre as falas dos acusados ganha sentido à vista da existência de uma lógica de relacionamento político que, baseada em padrões de uma "economia do dom", ${ }^{82}$ possibilitava aos indivíduos conseguirem auxílios, concessões e, sobretudo, ascensão social pautados pelos vínculos com o monarca. No entanto, se esse caminho proporcionou o encontro de personagens tão diferentes como Veiga e Torrezão, foi o mesmo que os levou ao fatídico episódio da devassa, ao esbarrarem, em suas conversações, no tênue limite entre o que seria ou não permitido nos quadros do controle almejado pelas autoridades joaninas. Foi quando se revelou impossível evitar que desentendimentos ou desavenças pessoais extrapolassem a esfera da intimidade, já que discutir política passara a ser hábito comum em espaços públicos, conforme eles mesmos se referiram. Desde o início, a reação de ambos foi defender-se, obviamente, atacando o outro com suspeitas não apenas de "revolução", mas de "desafeição" ao governo que, efetivamente, teve idêntica carga suspeita naquele contexto.

A despeito do destino que os aproximou, Manuel Luís da Veiga era um homem muito diferente de Francisco Xavier de Noronha Torrezão. Mais do que isso, ele confirmava estar, sem romper com práticas tradicionais de tipo Antigo Regime, no olho do furacão das transformações nos paradigmas político-econômicos que se operavam no mundo desde os setecentos. Isso fica especialmente evidente na justificativa que à "V.A.R" fez de sua inocência em comparação àquela feita pelo oficial graduado diretamente. Este último, como funcionário do Estado português há pelos menos vinte anos e egresso de uma família cujos membros gravitavam em torno de cargos administrativos,

${ }^{82}$ Termo usado pela historiografia para se referir ao ato régio de conferir honras e privilégios; ver Ângela B. Xavier e António M. Hespanha, "As redes clientelares”, A. M. Hespanha (coord.), História de Portugal. O Antigo Regime, Lisboa, Estampa, v. 4, p. 381-393. 
escreveu da cadeia uma carta ao príncipe regente D. João em que evocava os valores mais caros à monarquia portuguesa. ${ }^{83}$ Dizendo-se "prostrado aos Pés de S.A.R.(...) beijando-lhe, humilde, grato, e sempre fiel", suplicava-lhe perdão por não ter falado da dita "revolução" às autoridades legítimas, acentuando a pureza das suas intenções no caso. "Eu posso errar, e erro; porque sou Homem: não posso ser criminoso nunca, porque sou Católico, e bom Vassalo. Não posso ser ingrato ao meu Augusto Príncipe e Senhor, porque não o sou para ninguém", escrevia Torrezão. ${ }^{84}$

Veiga, sem deixar de frisar os valores "patrióticos" que o moviam como "vassalo fiel de S.A.R.”, investe na exposição do caráter utilitário de sua ação para o "bem da Nação". Frisa que tanto "sua conduta e vida privada até o ponto desta história é conhecida por todas as pessoas e Negociantes das Praças de Lisboa, Pernambuco, Bahia e Rio de Janeiro" - e, portanto, destituída de qualquer segredo -, como ele "não é um membro estéril para a Sociedade como mostram as suas obras do Comércio", e sua atividade mercantil desempenhada "há quatorze anos". ${ }^{85}$ No plano principal das suas justificativas, Veiga coloca, sobretudo, suas qualificações técnicas, razões importantes de seu valor pessoal já evocadas na carta a favor dos privilégios especiais para sua fábrica. Seu discurso está permeado de um caráter pragmático cuja valorização e racionalização dos ofícios remete, pelo menos, à preocupação desde os ilustrados setecentistas. Desse modo, diferentemente de Torrezão, que vincula sua inocência a um passado de distinção familiar na prestação dos serviços ao monarca, o fabricante acena para o futuro, para os frutos que poderiam advir de sua obra à indústria nacional.

A partir desse panorama, entende-se igualmente a questão das punições. Como foram poucas as testemunhas, e praticamente nada ficou realmente comprovado, a única consideração que Paulo Fernandes Viana fez do caso é que, pela acareação entre ambos, "Manoel Luis da Veiga não variou, nem vacilou e Torrezão variou em muitas respostas, e vacilou em outras", motivo que o levou a conjeturar sobre a culpabilidade do oficial. ${ }^{86}$ Mesmo assim, o próprio

\footnotetext{
${ }^{83}$ ANRJ, Devassa de 1810, carta de 23 de agosto, fl. 81 e seg.

${ }^{84}$ Idem, fl. 83v. Na carta, Torrezão elenca uma série de "benefícios" que recebeu do príncipe - inclusive o perdão pela participação, em 1801, na loja maçônica de Lisboa - e daí a "impossibilidade" de ser infiel ao monarca. É com os valores mais caros ao absolutismo que Torrezão apela aos "erros" cometidos por todos os homens e nega veementemente ser "criminoso". E será, em 1815, com os mesmos argumentos, que ele justificará seu pedido de ingresso na Ordem da Torre e da Espada.

${ }^{85}$ ANRJ, Devassa de 1810, fl. 73v.

${ }^{86}$ Idem, fl. 79.
} 
Viana, diante da falta de provas, arrematou "que nenhum se pode entender que não seja criminoso", ${ }^{87}$ pois, além de seus comportamentos estarem longe de ser exemplares, o processo permaneceria cheio de lacunas. Fossem ou não culpados, os meses que passaram na prisão já significavam, na visão do mesmo intendente, uma punição de não pequena monta. No entanto, a Torrezão, como funcionário régio, coube pedir perdão frente ao príncipe regente numa mostra da pedagogia política do absolutismo a que Veiga, como ilustrado homem de "ofícios" e "negócios", aparentava não se enquadrar.

Em uma breve reflexão sobre o tipo de acusação que lhe fora imputada, Veiga demonstrou, mais uma vez, sua pragmática perspicácia quando fez uma avaliação da verossimilhança do caso. Ele negou enfaticamente que pudesse haver um movimento que começasse "com gritaria e grande ajuntamento de Moleques, (...) uma molecagem", de onde deveriam "aparecer então os Negociantes". ${ }^{88}$ Para tanto, listou sete razões que comprovariam sua impossibilidade, entre as quais a de que "não era natural que se fizesse uma revolução contra o Estado feitas por Negociantes, homens brancos, e negros, quando sempre são inimigos uns dos outros". E ajuntou que "para desunir os Moleques bastariam doze soldados", já que não seria "natural" o caso acontecer "nesta Corte aonde há Regimentos". ${ }^{89}$ Dessa forma, tocava num ponto nevrálgico sobre um motim ou revolução nestes moldes: os antagonismos sociais que impossibilitavam tanto sua realização como uma comunhão de interesses num projeto coeso de transformação social. Era assim que a existência da escravidão colocava evidentes dificuldades a uma eventual prática revolucionária. Como se sabe, sete anos depois em Pernambuco, essa mesma questão voltaria à tona quando a evocação da "soberania do Povo" ousaria expressar a "perfeita igualdade" de cada um numa sociedade marcada por um fosso verdadeiramente intransponível..$^{90}$ Veiga, como muitos dos outros proprietários e negociantes então envolvidos no movimento de 1817, sabiam bem disso.

\footnotetext{
${ }^{87}$ Idem, fl. 5.

${ }^{88}$ Idem, fl. 47.

${ }^{89}$ Idem, fl. $72 \mathrm{v}$.

${ }^{90}$ István Jancsó e João Paulo Pimenta, "Peças de um mosaico (ou apontamentos para o estudo da emergência da identidade nacional brasileira)", Carlos Guilherme Mota (org.), Viagem incompleta. A experiência brasileira (1500-2000). Formação: histórias, São Paulo, Ed. Senac, 2000, p. 158-159.
} 
A trajetória política de Manuel Luís da Veiga - ou o que foi possível aqui recuperar dela - tem a validade de possuir características emblemáticas para o período enfocado. Nesse sentido, a devassa da qual foi alvo em 1810, aparentemente uma peça incoerente e desprovida de sentido, permite que se conectem várias facetas da ação do mesmo personagem que, de comerciante, virou fabricante em terras americanas. Não há como negar que lhe seja tributada a permanência de um substrato ideológico de tipo mercantilista - se quisermos realmente nos centrar nas classificações -, pois que mantém clara a bandeira da intervenção do Estado para favorecimento da classe dos "vassalos úteis" para prosperidade do Império, "negociando" na esfera da política. Da mesma forma, é verdadeiro que também falasse em nome de uma camada de negociantes e produtores do Reino, visivelmente prejudicada com a difusão das idéias de liberdade de comércio, sobretudo após 1808. Não à toa, nesse ano, escolheria o Brasil para viver.

Nesse sentido, estar em um mundo com paradigmas em transformação impeliu Veiga a novas ações. É notável como já pregava, desde sua estada na Inglaterra, uma crítica pública às ações do governo, logo contribuindo para a gestação de novas formas de sociabilidade política no ambiente da corte carioca, já incontroláveis por parte dos órgãos régios. A despeito de agir em nome dos tão esperados privilégios - o verdadeiro leitmotiv que o fez ir até o Rio de Janeiro -, não se tratava de obter favores para uma classe onerosa de nobreza, mas de condições para a "elite ilustrada" desenvolver internamente uma nova "Nação". Entendê-lo integralmente como um homem de sua época - como todos o são sempre - permite adentrar na complexidade do cenário em que atuou e ter em mente a permanente relação de ruptura-continuidade dos enredos da História. 